\title{
Az Internet és a civil társadalom
}

Miközben a civil társadalom az online megjelenésre törekszik, bizonyos aggasztó trendek kezdenek felbukkanni. Ez a tanulmány az aggodalomra okot adó jelenségeket vizsgálja, az alábbi öt főbb területen: egyenlőtlenség, gyengülő társadalmi kötelékek, csökkenő mértékű felelős közgondolkodás, elburjánzó fogyasztói szemlélet, és a magánélet sérüléseinek a társulási szabadságra gyakorolt hatásai. A tanulmány célja nem baljós előrejelzések tétele az Internet valószínű hatásairól, amelyeket a civil társadalomra gyakorolhat. Az Internet jótékony hatásúnak is bizonyulhat, ám ez nem igazolja, hogy elhanyagoljuk a potenciális kockázatokat. Az Internet nem hibáztatható azért, ha a civil társadalom helyrehozhatatlanul meggyengül: mi magunk érdemeljük meg a szemrehányásokat, ha elmulasztjuk, hogy időben cselekedjünk.

\section{Szerzői információ:}

\section{Peter Levine}

Peter Levine (www.peterlevine.ws) a Civil társadalom tanulási és közéleti részvételi információs és kutató központjának (Center for Information and Research on Civic Learning and Engagement, CIRCLE) igazgatóhelyettese, valamint a Marylandi Egyetem Filozófiai és Közigazgatás-politikai Intézetének kutatója. Filozófiai tanulmányait a Yale Egyetemen végezte, majd Oxfordban doktorált 1992-ben. Számos tudományos társaságban és bizottságban töltött be különféle vezetôi tisztségeket. Nietzsche munkásságával foglalkozott (Nietzsche and the Modern Crisis of the Humanities. SUNY Press, 1995); írt egy politikai regényt is (Something to Hide, St. Martin's Press, 1996). Kutatási területe korábban általános filozófiai és morális kérdésekre terjedt ki, érdeklődésének középpontjában jelenleg a deliberatív demokrácia és az ifjúság problémái, az iskolák civil társadalmi missziója, valamint a civil társadalom online szervezôdése és megjelenési formái állnak.

Így hivatkozzon erre a cikkre:

Levine, Peter. „Az Internet és a civil társadalom”. 
Peter Levine

\section{$\mathrm{Az}$ internet és a civil társadalom ${ }^{1}$}

A civil társadalom az internet felé orientálódik. Minden szervezet honlapokat használ fel tagtoborzásra, társadalmi kapcsolatok kiépítésére, önmaga megismertetésére, szponzorok keresésére és tagjainak tájékoztatására. A polgárok a világháló oldalairól szerzik be értesüléseiket és e-mail üzeneteken keresztül vitatják meg a közéleti ügyeket. Az egyházközségek tagjai elektronikus részvéttáviratokat küldenek a gyülekezetükhöz tartozó gyászoló családoknak. Különféle hobbik megszállottjai az internet speciális csatornáit felhasználva cserélik ki tapasztalataikat és a számukra értékes tárgyakat, s ugyanígy kérnek és kapnak tanácsokat.

Ám miközben a civil társadalom az online megjelenésre törekszik, bizonyos aggasztó trendek kezdenek felbukkanni. Ez a tanulmány az aggodalomra okot adó jelenségeket vizsgálja, az alábbi öt fốbb területen: egyenlốtlenség, gyengülố társadalmi kötelékek, csökkenó mértékú felelős közgondolkodás, elburjánzó fogyasztói szemlélet, és a magánélet sérüléseinek a társulási szabadságra gyakorolt hatásai. A tanulmány célja nem baljós elốrejelzések tétele. Az internet jótékony hatásúnak bizonyulhat a civil társadalmi élet szempontjából, ám ez nem igazolhatja a potenciális kockázatok elhanyagolását.

\section{Egyenlőtlenség}

Az internetnek a civil életre gyakorolt jelenlegi hatásaival kapcsolatban az elsố(és a legszélesebb körben tudatosult) okot az aggodalomra az adja, hogy az emberek csak akkor tudják hatékonyan kihasználni a számítógépeket, ha elegendô pénzük, jártasságuk és fizikai hozzáférési lehetôségük van a nagy sebességú összeköttetések igénybevételéhez. Az Egyesült Államokban a jövedelem, a faji hovatartozás, a képzettségi szint és az életkor alapján elöre jelezhetô, hogy az emberek milyen mértékben használják a számítógépeket és a számítógép-hálózatokat - ugyanez a nemi hovatartozásról azonban már nem mondható el.

A Clinton-adminisztráció idején ez a „digitális megosztottság” fontos témát jelentett Washingtonban. A kongresszus mindkét nagy párt támogatásával megszavazott három fontos fejlesztési programot. Az úgynevezett E-rate adónem bevezetése az iskolák hálózati kapcsolatainak kiépítéséhez biztosít állami támogatást, a technológiai lehetôségek bóvítését célzó TOP program (Technology Opportunities Program) a kormányzati és a

${ }^{1}$ A fordítás a szerző javaslatára a tanulmány legújabb változata alapján készült (Peter Levine: The Internet and Civil Society. In Verna V. Gehring (ed.): The Internet in Public Life. Rowman \& Littlefield, 2004, 79-98. 
nonprofit szektorban mozdítja elő a digitális technológia alkalmazását, a közösségi technológiai központok programja (Community Technology Centers Program) pedig a szegény városi körzetek és az elmaradott vidéki területek ezen a téren végrehajtandó fejlesztésére irányul. Bush elnök megválasztásával a dolgok hamarosan megváltoztak: az új adminisztráció véget kívánt vetni azoknak a különféle szövetségi programoknak, amelyeknek a célja a digitális megosztottság megszüntetése volt.

Ennek a váltásnak elsôsorban ideológiai okai voltak, ám ezeket látványos statisztikákkal is alátámasztották. Az USA kereskedelmi minisztériumának jelentése szerint „1998 decembere és 2001 szeptembere között a legalacsonyabb (évi 15 ezer dollárnál kevesebb) jövedelmú háztartásokban élő személyek körében az internet használata 25 százalékos évi növekedési arány mellett - folyamatosan emelkedett”. Ez annyit jelentett, hogy a szegény lakosság is magáévá tette az internetet, mégpedig gyorsabb ütemben, mint a magasabb jövedelmú rétegek (melyeknek a tagjai közül a legtöbben már korábban is rendelkeztek online hálózati kapcsolatokkal). Ugyanez vonatkozott az alacsonyabb képzettségú csoportokra is, és a nemek közötti szakadék teljesen eltúnt. Úgy látszott tehát, mintha a piaci erốk már jó úton járnának a digitális megosztottság problémájának megoldásában, mivel a vállalatok versengtek egymással, hogy a szélesedố piacokon egyre olcsóbb és mindenki számára egyre vonzóbb szolgáltatásokat nyújtsanak. Míg az USA kereskedelmi minisztériumának az internethasználatról készített 1999. évi jelentése még az „Átesünk a hálón” (Falling Through the Net) címet viselte, a 2002. évi jelentés címe már ez lehetett: „Egy nemzet online” (A Nation Online).

Számos okunk van azonban arra, hogy továbbra is aggódjunk az esélyek egyenlóségéért. Elôször is, az 1998-2002 időszakra vonatkozóan jelzett gyors növekedés részben az olyan szövetségi programok eredménye volt, mint például az E-rate, amelyet most a megszüntetés fenyeget. A veszély világossá válik, ha számításba vesszük, hogy az alacsony jövedelmú rétegek számára igen fontos az iskolákon és a könyvtárakon keresztül való hozzáférés az internethez, amit a szövetségi kormány támogatása tesz lehetôvé. A legszegényebb és a leggazdagabb gyerekek számítógép-használatának mértéke között mindössze 12 százalékos különbség mutatkozik, ez azonban azért van így, mert az alacsony jövedelmú családokból érkezố diákok az iskolában használják a számítógépeket. Az otthoni számítógép-használat tekintetében majdnem 60 százalékos különbség van a leggazdagabb és a legszegényebb diákok között. Hasonlóképpen, az afrikai-amerikaiak valamennyi korcsoportja a fehéreknél 10 százalékkal nagyobb valószínúséggel használja az internetet valamely közkönyvtárban, mivel kevésbé valószínú, hogy otthon van internet-összeköttetésük. Ha a könyvtári és iskolai számítógép-használat szövetségi támogatásai megszúnnek, akkor a digitális olló hamarosan újra szétnyílik.

Ugyanakkor az iskolai vagy könyvtári internethasználat nem teljes mértékben kielégítô. A felhasználók ideje szúkre szabott lehet, és a berendezések használatára vonatkozóan az intézmények elóírhatnak bizonyos korlátozó szabályokat. Minden bizonnyal nehéz lenne például egy könyvtárból múködtetni valakinek a saját honlapját, vagy egy nyilvános használatra szolgáló számítógép alapszintú beállításai mellett tanulni meg valamely szoftver alkalmazásait. A munkahelyi internet-hozzáférés gyakran még kevésbé kielégítő, mivel a munkáltató kategorikusan megtilthatja eszközeinek magáncélú vagy társadalmi és politikai célokra való felhasználását. 
Harmadszor, nem tudom elhinni, hogy az internethasználat gyors növekedése az alacsony jövedelmú rétegekben mindaddig folytatódni fog, amíg az egész lakosság „hálózati polgárokból" fog állni. Az amerikai felnóttek több mint 20 százaléka az írni-olvasni tudás legalacsonyabb szintjén áll, ami annyit jelent, hogy a társadalombiztosítási kártya kiadását célzó kérelemhez rendszeresített úrlapon nem képes a személyére vonatkozó információkat megadni, vagy nem tud összegezni néhány költségadatot egy megrendelési nyomtatványon. Ezek az emberek nem sok hasznát fogják venni az otthoni számítógépnek.

Negyedszer, az alacsony jövedelmú családokban komoly stresszt okozhat, ha belátják, hogy szükség van az otthoni számítógép beszerzésére. Sok szülő attól fél, hogy gyermekei jövóbeli kilátásait károsítja, ha nem sikerül otthoni internet-összeköttetést biztosítaniuk. 2001-ben a New York Times beszámolt egy bajba került háztömbról Harlemben, ahol ,az elszegényedett anyák - attól rettegve, hogy gyermekeik lemaradnak a tanulásban - elkezdtek számítógépeket lízingelni”. Ez azt jelenti, hogy a szegény családok ugyan képesek lehetnek legyốzni a digitális megosztottságot, de csupán más fontos célok feladása árán, és könnyen előfordulhat, hogy nem lesznek képesek lépést tartani a fejlő́déssel.

Végül pedig a gazdag háztartások nagyobb valószínúséggel csatlakoznak a hálózatra kábeles és egyéb nagysebességú, szélessávú összeköttetések felhasználásával, mint a szegény családok. Ez a szakadék mindaddig nem túl sokat számít, amíg az internet legnagyobbrészt még szövegeket és állóképeket közvetít. Ám ahogy a szélessávú kapcsolatok egyre elterjedtebbé válnak, mind több és több honlap fog rafinált animációs elemeket is tartalmazni, sốt ez a tendencia már az e-mail üzeneteknél is érvényesül. Ekkor pedig az alacsony jövedelmú rétegeknek teljesen újfajta digitális megosztottsággal kell szembenézniük. 'Ténylegesen megfigyelhetô az a történelmi minta, amely szerint az új technológiákat elôször csak a gazdagabb és magasabb szinten iskolázott rétegek alkalmazzák, majd ezek az eszközök olcsóbbá válnak, szélesebb körben is elterjednek, és ekkor - mivel a fóbb intézmények már ezekre támaszkodnak - nélkülözésük a mindennapi életben is határozottan kellemetlenné válik. Késóbb már nem biztosítanak viszonylagos elốnyöket, ezután viszont - hasonló ciklust követve - újabb technológiák születnek meg és terjednek el, amelyek felváltják vagy kiegészítik óket.

Mindebból nem szükségképpen következik az, hogy a szövetségi kormánynak közvetlenül támogatnia kellene az otthoni számítógépek és hálózati kapcsolatok biztosítását mindaddig, amíg a digitális megosztottság el nem túnik, ugyanis az ilyen támogatás költségvetési prioritásokat biztosítana a megcélzott haszonélvezók számára. Ezek tehát internet-hozzáférést kapnának ahelyett, hogy például megjavíttathatnák az autóikat, amire esetleg nagyobb szükségük lenne. Véleményem szerint ahelyett, hogy célzott támogatást nyújtunk olyan javak beszerzéséhez, mint az internet-hozzáférés, inkább a rugalmas jövedelmi támogatást kellene kiterjeszteni, olyan mechanizmusok révén, mint például a jövedelemadó-hitel (Earned Income Tax Credit). A társadalom egészében véve minden bizonnyal hasznot húzna abból, ha mindenki rendelkezhetne hálózati kapcsolatokkal, mivel erre támaszkodva a kormányzati szervek megszüntethetnék például a papíralapú ügyintézési formákat. A tényleges 100 százalékos internethasználat azonban lehetetlennek bizonyulhat. 
A digitális megosztottság tekintetében nem érvelek tehát semmiféle konkrét kormányzati stratégia mellett. Mindössze annyit mondok, hogy az egyenlőtlenség továbbra is probléma marad, és ez közvetlenül kihat a civil társadalomra. Noha a gazdagok úgy találhatják, hogy a számítógépes hálózatok lehetôségeinek kihasználásával a civil társadalom izgalmasabbá és vonzóbbá válik, a szegényebb és kevésbé képzett emberek esetleg csak a hagyományos, személyes kapcsolatokra épülő helyi társulási módozatok alternatíváját választhatják. Még rosszabb kilátás, hogy azok a csoportok is áttérnek az internet használatára, amelyek eddig szélesebb társadalmi kört fogtak át, és ennek folytán elveszítik szegényebb tagjaikat.

Az esélyegyenlőség ilyen problémái az iparosodott országokban - ha a bolygónk déli féltekéjén uralkodó helyzettel vetjük össze óket - igen csekélyek. A számítógép-hálózatok hosszú távon talán erôsíteni fogják a nemzetközi civil társadalmat, valamint a független szervezetek és társulások egész sorát minden országban. A világ legnagyobb részén azonban az internet egyelôre még csak igen kis mértékben van jelen. Az ENSZ fejlesztési programjának statisztikái szerint az ipari országok 1999-ben a Föld lakosságának 15 százaléka számára nyújtottak otthont, ám itt élt az internetfelhasználók 88 százaléka, míg Afrikában a lakosságnak mindössze fél százaléka rendelkezett internet-hozzáféréssel. A világ összes országának egy negyedében ma is egynél kevesebb telefon jut száz emberre, s ez rövid távon reménytelenné teszi az internet-hozzáférés széleskörú elterjedését.

\section{Gyengülố társadalmi kötelékek}

Egyes megfigyelók attól tartanak, hogy az internet a robusztus, tartós és érzelmileg kielégítő társadalmi kötelékeket felszínes és esetleges kapcsolatokkal váltja fel. Az emberek általában nem fogják a bizalom és a kölcsönös elkötelezettség erôs kötelékeit kiépíteni, ha a számítógépek válnak legfóbb kommunikációs eszközükké. Talán többet fognak kommunikálni, mint eddig bármikor, amikor azonban szükséghelyzetben találják magukat, könnyen meglehet, hogy nem lesz kihez fordulniuk.

Ezt az elốrejelzést az internethasználatról végzett amerikai felmérések nem támasztják alá. Az USÁ-ban az 1996. évi országos választási felmérés feltárta, hogy az internethasználók több szervezethez kötődtek offline, a valós világban, mint mások, és ezek a „hálózati polgárok” általában bizakodóbbak voltak. Az efféle általános megállapítások igaznak bizonyulnak akkor is, ha csak a hasonló képzettségi és jövedelmi szintú embereket hasonlítjuk össze. A Kaliforniai Egyetem Los Angeles-i kampuszának kutatói által 2000-ben végzett felmérés szintén azt mutatta ki, hogy azok, akik használták az internetet, valamivel több idót töltöttek különféle klubokban és szervezetekben való részvétellel, mint azok, akik sohasem használták a számítógép-hálózatokat. Ugyanakkor az internethasználók kisebb valószínúiséggel alkalmazták önmagukra a „magányos” jelzốt. A Pew kutatási központ „Internet and American Life” címú programjának keretében 2001-ben végzett felmérés szerint az internethasználók az internetet nem használó válaszadóknál jelentôsen nagyobb valószínúséggel tudták megmondani szomszédaik nevét, és gyakrabban tartoztak különféle társaságokhoz.

Röviden: azok, akik használják az internetet, aktívabb résztvevói a civil társadalomnak, mint azok, akik nem létesítenek hálózati kapcsolatot. Ez a korreláció azonban 
nem bizonyítja, hogy az internethasználat elómozdítaná a civil aktivitást. Lehet valami más is, ami az internethasználókat arra készteti, hogy részt vegyenek különféle csoportok tevékenységeiben: ha nem a jövedelmük és a képzettségük, akkor esetleg a koruk, az energiájuk, a családi helyzetük vagy az aktuális trendekre való általános fogékonyságuk is fontos motiváló erô lehet. Az ilyen emberek korán alkalmazni kezdik azokat a technológiákat, amelyeket a lakosságnak még a fele sem használ: bármilyen személyes jellemvonásuk helyezi is óket az internet-hozzáférés élvonalába, ugyanaz késztetheti óket az offline csoportokban való aktív részvételre is.

Ennélfogva tehát alapvetô fontosságú, hogy véletlenszerúen kiválasztott lakossági mintákon, az idô elốrehaladásának figyelembevételével is mérni tudjuk az internethasználat hatásait. 1998-ban a Carnegie Mellon Egyetem HomeNet programjának keretében folytatott kutatások feltárták, hogy azok a pittsburgh-i lakosok, akik számára a program során internet-hozzáférést biztosítottak, kezdtek kissé kevesebbet kommunikálni saját háztartásuk más tagjaival, és társadalmi hálózataik beszúkültek. A HomeNet program kutatói azt a hipotézist állították fel, hogy „,az emberek által az internet használatára szentelt idố azt az idốt váltja fel, amit korábban társadalmi tevékenységekre fordítottak”, továbbá „az emberek az interneten létesített gyengébb minőségú társadalmi kapcsolatokkal váltják fel a jobb kapcsolatokat, vagyis az erős kötelékeket gyengébbekre cserélik fel". A résztvevók beszámoltak a depresszió fokozódásáról is az internethasználat kapcsán. Ezt a tanulmányt széles körben bírálták, egyebek között azért, mert a kutatók nem vettek figyelembe olyan kontrollcsoportot a pittsburgh-i lakosok között, akiknek nem volt internet-hozzáférésük. Ám a Stanford Intézet egy ezt követô kísérlete a társadalom kvantitatív vizsgálatára (Quantitative Study of Society) hasonló eredményekhez vezetett. Az intézet 35 ezer olyan embernek biztosított egyszerú „webtévés” internetkapcsolatot, akik korábban nem rendelkeztek semmiféle hálózati összeköttetéssel. A kutatók úgy találták, hogy az új internethasználók elkezdtek kevesebb idốt tölteni családjukkal és barátaikkal, ritkábban látogattak el különféle rendezvényekre, és rövidebb idốt fordítottak újságolvasásra.

Ha ezt a két kísérletet összevetjük az 1996. évi országos választási felmérés adataival, a következó próbahipotézist állíthatjuk fel: Azok az emberek, akik bármikor használhatják az internetet, társadalmilag aktívabbak, mint azok, akik nem kapcsolódnak a hálózatokra. Ennek oka azonban egyesek esetében az is lehet, hogy jobb anyagi helyzetben vannak, míg másokat esetleg éppen a civil társadalmi hálózatok munkájában közremúködő barátaik győznek meg arról, hogy érdemes rákapcsolódni az internetre; megint mások pedig talán egyszerúen csak aktív, energikus és optimista emberek, akik egyrészt szívesen magukévá teszik az új technológiákat, másrészt cselekvố módon részt vesznek közösségeik életében is. Ám igen csekély civil vagy társadalmi haszon származik magából az internethasználatból. Valójában a számítógép-hálózatok használatának következtében idôvel egy egész társadalom felelótlenebbé vagy atomisztikusabbá válhat.

Ennek egyik fơ oka az anonimitás, valamint a másoktól való pszichológiai eltávolodás, bizalmatlanság és felelótlenség, amit ez gyakran kivált. Az anonimitás természetesen nem szükségszerúen jellemzi a számítógépes hálózatok használatát. Órákig ülök a számítógépemnél minden nap. Ennek az idő́nek nagy részét általam jól ismert emberektôl kapott e-mail üzenetek olvasásával és azok megválaszolásával töltöm. 
Egy vállalat vagy egy közigazgatási szerv megkívánhatja klienseitól, hogy tárják fel valódi identitásukat az interneten és bizonyítsák kilétüket valami olyasmivel, mint például egy hitelkártyaszám, és valamely szerzốdésben meghatározott megállapodásnak megfelelóen viselkedjenek. Az internet azonban - különösen a csevegó-fórumokon, a levelezólistákon és a játék-környezetekben - az ilyen kapcsolatokon kívül megteremti a kölcsönhatások egy új rétegét is, amelyben a résztvevoók visszatarthatnak gyakorlatilag minden önmagukra vonatkozó információt, beleértve nevüket, külsố megjelenésüket, demográfiai jellemzố vonásaikat és földrajzi hollétüket. Bármikor megszakíthatják a kontaktust, tetszés szerint felvehetnek többszörös személyiségeket és identitásokat, és megvédhetik magukat annak a következményeitól, amit mondanak. Ugyanezt a hatást száz évvel ezelótt talán az anonim postafiókok kifinomult rendszerén keresztül lehetett elérni, de csak nagy költséggel és kényelmetlenségek árán. A széleskörú anonimitás új jelenség, amely - legalábbis sokakra közülünk - nagy vonzóerôt gyakorol.

Az anonimitás, az alternatív személyiségek ideiglenes felöltése, a társadalmi fogódzók hiánya, valamint az antiszociális viselkedés megbüntetésének nehézségei a tipikus online interakciók jellegzetes vonásai közé tartoznak, s mindezek gyengítik a társadalmi gátlásokat és bátorítják a sértô vagy ellenséges viselkedést. (Ennek egyik példája az úgynevezett flame, ami valamelyik kommunikációs partner megnyilatkozásaira való extravagáns, durva és sértố reagálást jelent.)

Helytelen volna azonban ebból olyan meggondolatlan következtetést levonni, hogy az effajta „kívülmaradás” rossz dolog. Ha az interneten képesek vagyunk eltitkolni az önmagunkra vonatkozó információkat, ez néha annyit jelent, hogy a faji és nemi hovatartozásra vonatkozóan teljesen megszabadulhatunk a diszkriminációtól. Kaliforniában Santa Monica városa például a közösségi terekben elhelyezett ingyenesen használható terminálokon keresztül hozzáférést biztosított az egész lakosság részére a $P E N$ elnevezésú helyi e-mail hálózathoz. Ennek egyik eredményeként a város korábban megvetett és kirekesztett hajléktalanjai aktív résztvevókké váltak a hajléktalanság problémájával kapcsolatos városi stratégia kidolgozásában. A hajléktalanoktól befutó tanácsokat követve Santa Monica önkormányzata elkezdett ingyenesen igénybe vehetó zuhanyozókat, mosdókat és csomagmegớrzóket felállítani a városban. Az egyik polgár, Donald Paschal az alábbiakat írta:

„Hajléktalan vagyok... Miránk, akiknek nincs tetố a fejünk fölött, lenézéssel, félelemmel, utálattal, szánakozással vagy gyúlölettel tekintenek. Ez a megkülönböztetés majdnem lehetetlenné teszi számunkra a más emberekkel való 'normális' kapcsolatokat. Nemcsak arról van szó, hogy esetleg piszkosak vagyunk és talán rossz szagunk is van, hanem arról, hogy mások vagyunk. Sokan úgy gondolják, hogy azokat az embereket, akik mások, el kell kerülni. Santa Monica $P E N$ rendszere éppen ezért jelent számomra olyan különleges értéket. A $P E N$-rendszerben senki sem tudta, hogy hajléktalan vagyok, mindaddig, amíg meg nem mondtam nekik, ám miután megmondtam, továbbra is emberi lényként kezeltek. Számomra a leginkább figyelemre méltó dolog a $P E N$-közösségben az, hogy egy városi tanácstag együtt élhet azzal, aki szegény, nem feltétlenül mindig teljes harmóniában, de egyenlő alapokon. Találkoztam és összebarátkoztam - vagy néha ellentétbe kerültem - olyan emberekkel, akiket másképpen nem ismerhettem volna meg." 
Ez inspiráló történet, de bizonyos fenntartásokkal kezelendő. Donald Paschal nyilvánvalóan jól fejezi ki magát írásban, tehát iskolázottnak kell lennie (még akkor is, ha sikeres autodidakta). A képzettségi szintból, az anyanyelvi vagy nyelvjárási háttérból és néha a nemi hovatartozásból fakadó különbségek érzékelhetók maradnak online környezetben is.

A legalábbis részben megốrzött anonimitás lehetôsége azonban pallérozhatja a közösséget oly módon is, hogy ösztönzi a pártatlanságot, az elfogulatlanságot és a személyes nyíltságot, fóleg a másokkal közösen viselt stigmák esetében. A HomeNet és a Stanford Intézet tanulmányai azt állapították meg, hogy az internethasználat következtében az állampolgárok - általában - elszigeteltebbé válnak. Vannak azonban fontos kivételek. Az internet érintkezésbe hozhatja az embereket másokkal, akik az övékhez hasonló speciális körülmények között élnek, vagy osztoznak velük meggyoóződéseikben és kétségeikben, lehetôvé téve ezáltal jelentős lelki kötődések kialakulását. Egy információs rendszerekkel foglalkozó professzor, Jenny Preece azt állítja, hogy a közös egészségi problémákkal küszködố emberek online múködő „empatikus” közösségeket alkotnak, és bizonyítékokat sorol fel az információk megosztásának és magas szintú érzelmi támogatásnak a meglétére ezek körében. A közösségek néha mélyebb kapcsolatokat biztosítanak, ha magunk választhatjuk meg partnereinket, nem pedig csupán születésünk folytán kerülünk bele a helyi kapcsolatok hálózataiba.

Még ha az online közösségek általában gyengébbek is, mint a valóságos világban létezók, ezek elónyökkel is járhatnak, mivel választási lehetôségeket nyújtanak: az internet jól esố kiszabadulást biztosíthat a család, a szomszédság, az iskola vagy az egyházközség idő́nként nyomasztó világából, ami gyakran elnyomó politikai felhangokkal is terhes.

Bruce Bimber politológus különbségtétele a „sưrú” (thick) és a „ritka” (thin) közösségek között itt fontos szerepet játszik. Az emberek azért csatlakoznak a ,ritka” közösségekhez, mert már rendelkeznek közös meggyốzódésekkel, értékekkel vagy célokkal, és úgy gondolják, hogy az együttmúködésból stratégiai hasznot húzhatnak. Feliratkozhatok például egy levelezólistára azért, mert arra számítok, hogy az ebból származó haszon (például valamely speciális tárgyra vonatkozó információ) számomra megéri, hogy vállaljam a „költségeket” (például a postafiókom telezsúfolását). Késốbb - csupán kötelességérzetból - magam is hozzájárulhatok információkkal a listához, valószínúleg ki fogok azonban szállni, mihelyt úgy látom, hogy a részvétel általános „költségei” meghaladják a hasznokat. Így tehát a levelezólista - ha azt egyáltalán „közösségnek” nevezhetjük - erốsen eszközjellegú marad számomra. Megkíván ugyan bizonyos mértékú kölcsönös bizalmat, a tagok egymás iránti bizalma azonban feltételes és korlátozott lehet. Ezzel szemben a „súrú” közösségekben a tagok elkötelezettek a csoport belsố értékei, a többi tag mint partner és a kollektívan elfogadott célok vagy értékek iránt. A vallási, szomszédsági és családi közösségek legtöbbször „súrúek”. Ilyen „sưrư” közösségek kialakulása nehezen képzelhetô el kizárólag online szervezôdéssel, a valóságos világban való bármiféle megjelenés nélkül. A levelezólisták, a hirdetốtáblák és az online szerepjátékok elkötelezett résztvevối mindenesetre azt vallják, hogy online közösségeik valóban léteznek, és ók azokhoz tartoznak. Beszámolóikat azonban nem szabad névértéken elfogadnunk, mivel esetleg hiányzanak a „súrúbb” közösségekben szerzett tapasztalataik. 
A liberális társadalmakban a polgároknak joguk van kilépni az olyan önkéntes társulásokból, mint például a szakszervezetek, a politikai pártok, az egyházak, a testvériségi szervezetek vagy akár a családok. A kilépés könnyúsége kedvez az egyéni szabadságnak, és ezt az emberek - ceteris paribus - általában eloonyben részesítik az olyan fajta elnyomással szemben, ami a tagjaik kilépését akadályozó, erôs kontrollal múködő szervezetekben érvényesül. A civil társadalom szelleméból azonban az következik, hogy a kilépés szabadságának joga kombinálódik az erôs és fegyelmezett „súrún” társulások változatos sorával. Az ember például kiléphet egy hagyományos szakszervezetból vagy a családjából is, de ennek bizonyos ára van. Továbbá, az ilyen csoportokba csak az léphet be, aki vállalja a közremúködést és azt, hogy bizonyos meghatározott normákat tiszteletben tart. Az ilyen szervezetek a kizárás vagy a kirekesztés fenyegetésével még a liberális államokban is hatalmat szereznek arra, hogy bizonyos értelemben fegyelmezzék az egyéneket.

A fegyelmezett szervezetek ugyanakkor diszkriminálhatják a kívülállókat, és elnyomhatják a belsó hierarchiájuk alsó fokain elhelyezkedố embereket. Másrészt azonban megkívánják tagjaik általános hozzájárulását ehhez, és viszonzásként politikai erốt és bizonyos lehetôségeket biztosítanak az elóbbre jutáshoz. Így például a dolgozó osztályhoz tartozó fehérbőrú amerikai férfiak az 1950-es években számíthattak a demokrata párt, a katolikus egyház és a szakszervezetek meglehetôsen lojális szolgálataira. Reálisan elképzelhették, hogy pártvezetôk, kardinálisok vagy szakszervezeti elnökök lehetnek. Mindezek a társulások mostanra veszítettek taglétszámukból és politikai fontosságukból, részben azoknak a reformoknak az eredményeként, amelyek a belépés és a kilépés megkönnyítését szolgálták. Ma leginkább a nagyvállalatok tekinthetốk fegyelmezett és hatalommal bíró szervezeteknek, ezek azonban a szakképzetlen vagy nincstelen emberek számára keveset nyújtanak. Az önkéntes társulások szektora az 1950-es évek óta kétségkívül kevésbé diszkriminálóvá vált, ám egészét tekintve - a dolgozó osztályok fontos erőforrásaként - egyszersmind meg is gyengült.

Az internet várhatóan tovább fogja erôsíteni ezt a trendet. Valamely hírcsoporthoz vagy levelezólistához való csatlakozáshoz, illetve valamely honlap gyakori látogatásához az embernek rendszerint mindössze egy-két linkre kell rákattintania, és a kilépés éppen ilyen egyszerú. Elizabeth Reid megállapítja, hogy „,azok a felhasználók, akik online kapcsolatokban zavaró viselkedést tanúsítanak, olyan nyilvános rituálék szenvedố alanyaivá válhatnak, amelyeknek az a céljuk, hogy megszégyenítsék és megbüntessék óket”. Ezek a szankciók azonban online minden bizonnyal csekélyebb súlyúak, mint amilyenek a valóságos világban lennének. Az interneten létrejövô csoportok - könnyű belépési és büntetésmentes kilépési lehetôségeikkel - nem tudják tagjaikat hatékonyan fegyelmezni, és nem képesek legyőzni a közös cselekvés végrehajtása elớtt tornyosuló problémákat. Nincsenek eszközeik arra, hogy az embereket egymás szolgálatára, valamely közös célról való megfontolt közös gondolkodásra vagy az adott célok érdekében áldozatok vállalására késztessék. A hálózati csoportok a tágabb társadalomban - mivel az egyes tagok rendelkezésére álló forrásokat nem tudják saját céljaik szolgálatába állítani - viszonylag csekély erốt képviselnek.

A virtuális közösségek egyes lelkes hívei szerint a hálózati technológia lehetôvé fogja tenni az emberek számára, hogy le tudják gyốzni a közös cselekvés problémáit, anélkiil, hogy szükségképpen hierarchikus szervezetet hoznának létre. Azt állítják, hogy 
a közös célok eléréséhez többé nincs szükség sem tekintélyre vagy hatalomra, sem piacokra, mivel már beléptünk a „szegmentált, többközpontú, ideológiailag integrált hálózatok" (Segmented Polycentric Ideologically Integrated Networks, SPIN) korába. A SPIN típusú hálózatok a szabad akaratban hívôk közösségei, és múködésükhöz jól megfelelnek a nyílt számítógép-hálózatok. Magukban foglalják az 1970-es évek nốmozgalmait, a mexikói zapatista felkelés támogatóit, a neonáci szervezetek nemzetközi hálózatait és a globalizációellenes mozgalmat egyaránt. Ezek a hálózatok nem kényszerítik az egyéneket a közremúködésre és azt nem is fizetik meg, hanem tagjaikat a közös értékekkel motiválják, és a technológiát használják fel a tranzakciós költségek csökkentésére. „Az információs forradalom elôsegíti és megerôsíti a hálózatokat, miközben erodálja a hierarchiákat" - állítják. A pozitív programok kidolgozása és megvalósítása azonban majdnem minden esetben kollektív döntéshozatalt és bizonyos fegyelmet követel meg. A globalizáció-ellenes mozgalom kétségkívül tud tiltakozókat küldeni az utcákra, kétlem azonban, hogy képes lesz a nemzetközi kereskedelem új rendszerét megalkotni. Ha pedig a mozgalom fegyelmezetlen tagjai atrocitásokat követnek el, maga a mozgalom el fog halni.

\section{Az online közéleti gondolkodást fenyegető veszélyek}

Az emberi kötelékek és a bizalom mellett van még egy érték, amit az emberek a civil társadalomtól várnak: a felelős közéleti gondolkodás. A közvéleménynek elvileg irányítania, vagy legalábbis befolyásolnia kellene a demokratikus kormányokat. Az emberek azonban a fóbb közéleti kérdésekról nem automatikusan alakítanak ki jól átgondolt nézeteket. A polgárok az írásban vagy szóban folyó vitákban való részvétel vagy azok megfigyelése útján formálják ki a véleményüket, ami lehet bölcs vagy ostoba, önzô vagy altruista. Nézeteik fejlesztésére azonban a közös gondolkodás a legdemokratikusabb módszer. A megfontolt közös gondolkodás - anélkül, hogy a következtetéseket bárkire ráeróltetné - arra kényszeríti az egyéneket, hogy álláspontjukat megvédjék mások eloótt, akiknek más érdekeik lehetnek, vagy akik másféle háttérrel és más információkkal rendelkezhetnek. Ennek eredményeként a nyilvánvalóan önzó vagy ostoba elgondolásokat bizonyára el fogják vetni. Végül a közgondolkodás alapvető kommunikációs eszköz is a nagyközönség és a kormány között. A döntéshozók nem támaszkodhatnak csupán a választási eredményekre abban, hogy megbizonyosodjanak a közakaratról, mivel egy-egy szavazat értéke mindig többféleképpen értelmezhetố. Odafigyelés és párbeszéd nélkül a vezetốk nem lesznek képesek megismerni választóik értékeit és prioritásait.

$\mathrm{Az}$ internet otthont ad mindenféle elképzelhetô tárgykörnek szentelt vitacsoportoknak, levelezólistáknak, blogoknak és csevegófórumoknak, s így a politikai párbeszéd puszta mennyisége a hálózatok növekedése folytán valószínúleg növekszik. A közéleti viták minósége azonban rosszabbodhat is, mivel az internet lehetőséget ad a felhasználóknak a kommunikáció megszúrésére. A hagyományos média esetében kevés ellenơrzést gyakorolhatunk azok fölött a gondolatok fölött, amelyekkel találkozunk. Tekintsük például azt a személyt, aki elófizet egy napilapra, mivel saját karrierje, kedvenc sportegyesülete vagy helyi közössége szempontjából releváns, konkrét információkat kíván 
kapni, esetleg saját nézeteinek megerósítését várja a vele hasonló nézeteket tükrözốvezércikkektól. Miközben átlapozza az általános érdeklődésre számot tartó újságot, óhatatlanul megakad a szeme új gondolatokon, tóle idegen szemléletek megnyilatkozásain és más emberek életére vonatkozó izgalmas információkon. Az internethasználók mindezeket a gondokat elkerülhetik. Kereshetik csupán azokat az információkat és gondolatokat, amelyekre éppen kiváncsiak, biztonságosan megmaradva a hasonló nézeteket valló és hasonló érdeklôdésû emberek társaságában. Még az igen szokatlan ideológiák követôi is találhatnak olyan partnereket a világon, akiket szintén ugyanazok a meggyốzódések motiválnak. A szelektív olvasás valószínúleg egyidős magával az írással, és teljesen ésszerú módszert nyújt igen nagy mennyiségú információ kezeléséhez. Az interneten elérhetố keresốfunkciók azonban túlságosan megkönnyítik a szelektálást, és azzal fenyegetnek, hogy az egyensúlyt eltolják a hiperspecializálódás irányába.

Marshall van Alstyne és Eric Brynjolfsson informatikus kutatók elegáns bizonyítékot dolgoztak ki annak az állításnak az igazolására, hogy az „összekötöttség” - az a lehetôség, hogy sok emberrel gyorsan és olcsón tudjunk kommunikálni - ösztönzi az úgynevezett „,balkanizációt”, amit a különféle olyan elkülönült közösségek vagy életszituációk burjánzásaként szokás definiálni, amelyek nem állnak egymással kölcsönös kapcsolatban. A balkanizáció akkor következik be, ha az egyének nagyobb populációkból szabadon választhatják meg partnereiket, ha minden egyes személynek véges kapacitása van az információ felvételére, illetve feldolgozására, és ha a legtöbb embernek legalábbis enyhe preferenciái vannak a gondolatok és tények bizonyos típusai iránt. Hasonló logikával arra a következtetésre juthatunk, hogy az internet növelheti a társadalom intellektuális rétegezôdését, éppen azáltal, hogy az egyes kérdések szakértôi megengedhetik maguknak, hogy csak egymással kommunikáljanak és visszautasítsák a laikusokkal való kapcsolatokat.

Az amerikai kultúrában általános trend a változatos, többcélú szervezetektól (például a szakszervezetektôl, az országos egyházaktól és a földrajzi meghatározottságú erôs közösségektól) való eltávolodás, és a szúkebb élóhelyekre korlátozódó, egyetlen célú társulások felé való fordulás. Az olyan helyi szervezetek, amelyek azelő́tt különféle foglalkozású embereket vonzottak magukhoz, mint például a Masons és a PTA, elvesztették tagjaik többségét, miközben a partikuláris területeken létrejövő vagy sajátságos érdeklődést kielégítő országos szervezetek növekedtek. 1972 és 1992 között jelentôsen csökkent annak a valószínúsége, hogy az amerikaiak különféle csoportokhoz csatlakozzanak, látogassák azok rendezvényeit, olvassák újságjaikat és politikai céljaik iránt érdeklődést mutassanak - mindezek pedig annak az általános hajlamnak a kifejezối, hogy valaki szívesen lépjen interaktív kapcsolatba olyan személyekkel, akik különböznek tóle.

A világhálónak van két alapvetố technológiája, nevezetesen a hipertext és a keresőfunkciók, amelyek támogatják a felhasználókat abban, hogy megszúrjék azt, amit látnak és hallanak. Ezek állítólag felszabadító jellegú technológiák, mivel a felhasználók saját maguk dönthetnek arról, hogy melyik ösvényt kívánják követni, mit akarnak megnézni, és mikor mozdulnak onnan tovább. Az igazi szabadság azonban azt jelenti, hogy egy darabig valaki másnak a gondolatmenetét is képesek vagyunk követni. Az ember csak úgy szabadulhat meg saját eloóitéleteitól, ha kellóképpen alátámasztott érvekkel, jól átgondolt cselekménnyel, megfelelô hivatkozási háttérrel vagy minden apró részlet- 
re kiterjedő gonddal összeállított magyarázatokkal találkozik. Éppen ez az, amiért egy könyv olvasása rendkívül felszabadító hatású lehet. Nagyon sok könyv elérhető online is, beleértve Platón és Shakespeare összes múveit. Nem élhetjük bele azonban magunkat a platóni érvelés vagy a shakespeare-i szereplók világába oly módon, hogy kulcsszavakat keresünk vagy kattintások gyors sorozatával haladunk elóre a világhálón.

A privát szúrésnek káros társadalmi következményei lehetnek. Képzeljük el, hogy valaki nem érdeklődik a környezeti kérdések iránt, és általában nem hajlamos ezekról tudomást venni. Ha azonban ez a valaki már olvasott volna az újrahasznosítás értékéról valamely általános érdeklődésre számot tartó újságban (vagy látott volna valamilyen országos televízió-músort, amit ebben a tárgyban sugároztak), akkor talán maga is a szelektív hulladékgyújtést választaná. Mivel azonban ma beszerezheti az ôt érdeklő híreket az internetról is, anélkül, hogy a környezet védelmével kapcsolatos érvekkel és bizonyítékokkal is találkoznia kellene, lemondja az újság elófizetését, és sohasem fog megismerkedni az újrafelhasználás értékével. Ebben részben az internet vétkes.

Az internet kevés hatékony módot kínál az emberek számára ahhoz, hogy ügyüket olyanok figyelmébe ajánlják, akik eredetileg nem hajlamosak arra, hogy érdeklódjenek irántuk. Andrew Shapiro újságíró és ügyvéd azt állítja, hogy a világháló használói ritkán látogatnak el fizikailag létező közösségi terekbe, mivel „[a világhálón] nem kell a polgárjogi mozgalmak szószólóit hallgatniuk, nem kell szórólapokat átvenniük a sztrájkoló munkásoktól, és nem kell látniuk a mosdatlan hajléktalanokat. Világuk meg van tisztítva mindenféle interakciótól, kivéve azoktól, amelyeket kifejezetten kiválasztanak maguknak". Hasonló logikával állítottuk a fentiekben, hogy az internet növelheti a társadalom intellektuális rétegeződését, mivel a szakértók megtehetik, hogy csak egymással álljanak szóba, és ne vegyenek tudomást a közösség többi tagjáról.

Cass Sunstein politológus és jogtudós, aki sokat tett a céltudatos közgondolkodással kapcsolatos felfogásunk fejlesztéséért, a balkanizáció hátrányait „Republic.com” címú könyvében foglalja össze. Szerinte a balkanizálódott csoportok - egyebek között - hajlanak arra, hogy saját legradikálisabb tagjaik nézeteit fogadják el. Az ilyen csoportok tagjai nem értik meg mások felfogását és nem tanulják meg, hogy a tólük különbözố emberekkel hogyan létesítsenek kapcsolatokat. Nem ismerik fel, hogy egyes gondolatgazdag polgárok nem értenek egyet velük, s ezért azt feltételezik, hogy ha a kormány velük ellentétes álláspontot foglal el, ez csakis korrupció eredménye lehet. Folyamatosan megerôsítik saját meggyốzốdéseiket, a teljesen hibás nézeteket is beleértve, anélkül, hogy valaha is próbára tennék óket. Az a sok ember például, aki szembe helyezkedik a fegyverviselés szigorú ellenőrzésével, gyakran találkozhatott online a következő idézettel: „Ez az esztendő feljegyzésre kerül a történelemben! Most először vezeti be egy civilizált nemzet a fegyverek teljes körú ellenôrzését. Utcáink biztonságosabbak lesznek, rendốrségünk hatékonyabbá válik, és a világ a jövóben a mi példánkat fogja követni!" Ezt az idézetet a világhálón elérhetố számos honlapon Adolf Hitlernek tulajdonítják, aki állítólag 1935. április 15.-én így dicső́itette a fegyverek ellenőrzését a Berlin Daily címú napilapban (3. oldal, 2. cikk). Ezzel az állítólagos kijelentéssel kapcsolatban azonban minden közkeletú információ téves, beleértve azt is, hogy a náci kormányzat bevezette volna a fegyverek ellenốrzését. Csak az amerikai alkotmány második kiegészítését elemzố nyelvôrök esetében valószínú, hogy találkoznak az eredeti forrásával, az ő elkötelezettségük pedig sohasem kérdójelezôdik meg. 
Egy másik veszély az, hogy a „ritka” csoportok nem segítik elő a közgondolkodást olyan mértékben, mint ahogyan a „sưrư” hagyományos közösségek tették. Emlékezzünk rá, hogy az emberek azért csatlakoznak a „ritka” csoportokhoz, mert már magukévá tették azok közös céljait és értékeit. Dennis Thompson számos ilyen csoportot sorol fel, amelyekre az interneten bukkant rá. Csak néhány példa ezek közül: „Gyalogtúrázók parkjaink megtisztításáért”, ,Síposok országos uniója”, „Állampolgárok a nappalok megkurtítása ellen”, „Állampolgárok a finn-amerikai összefogásért”, ,Az USA bizottsága a perui forradalom támogatására”, „Anarchisták rágalmazásellenes ligája”. Ezeknek a csoportoknak a tagjai valószínúleg kevés időt töltenek központi értékeik vagy céljaik megvitatásával, mivel azok kezdettól fogva rögzítettek. Remélhetjük, hogy az egymással szemben álló ,ritka” csoportok vitákat is folytatnak egymással, ez azonban aligha történhet az interneten, mivel az emberek kiszúrhetnek bármit, amit nem akarnak hallani. Nincs közös tér, tömeges közönség, és nincsenek eszközök azoknak a megszólítására, akik nem találják meg maguktól is a szónokot.

Másrészt viszont egy „súrú” közösségben a tagok elkötelezettsége magát a csoportot erôsíti, noha annak céljai és értékei esetleg határozatlanok is lehetnek. Hacsak a csoport nem tekintélyelvú, tagjainak meg kell vitatniuk közös céljaikat, hozzájárulva a nyilvános közös gondolkodáshoz. A „súrú” szervezetek azonban ritkán jelennek meg online.

Ezzel összefüggó kérdésként veti fel Albert O. Hirschman társadalomtudós a saját vélemény hangoztatása (voice) és a csoportból való kilépés (exit) közötti ellentétet. Azok az emberek, akik nem teljesen elégedettek valamely csoporttal, amelynek a tagjai közé tartoznak, általában - az erôsen kényszerítố jellegú szervezetek kivételével (mint amilyenek például egyes katonai egységek és diktatórikus államok) - kétféle stratégia között választhatnak: Hallathatják a ,hangjukat”, vagyis panaszkodhatnak, változásokat követelhetnek, és ehhez megpróbálhatják mások támogatását is megszerezni, vagy pedig el is hagyhatják az adott társulást, és csatlakozhatnak egy másik csoporthoz. Az emberek tipikusan a legkisebb ellenállás útját követik. Ha például valamely demokratikus államból az egyetlen kivezetố út az emigráció, de a szólásszabadság alkotmányos védelmet élvez, akkor az állampolgárok tipikusan a hangjukat hallatják. Másrészt, ha a vállalatok a versenyszféra munkaerôpiacán nem veszik figyelembe az alkalmazottak panaszait, akkor az elégedetlen dolgozók hajlanak arra, hogy elhagyják ezeket.

Az, ha az emberek hallatják a hangjukat, illetve kilépnek valamely közösségból, társadalmi elónyöket ígér. Távozásukkal egy csoport tagjai csökkenthetik az adott szervezet súlyát, és ugyanakkor gyarapíthatnak más, számukra kívánatosabb közösségeket. Röviden: azt az eszközt, melynek segítségével a távozás haladást hoz létre, a verseny jelenti. A felszólalások, melyeknek a megvitatása során a csoporttagok fennhangon gondolkodnak arról, hogy társulásuk múködését hogyan lehet tökéletesíteni, közvetlenebb módon múködnek, valószínúnek látszik azonban, hogy az egyes csoportokból való kilépés az interneten jóval gyakoribb, mint az ellentétes nézetek hangoztatása, s így nem a közös gondolkodás, hanem a verseny válik dominánssá. Az interneten alapuló csoportokat nagyon könnyú elhagyni, de az ilyen csoportokban uralkodó normákat nehéz megváltoztatni, mivel nincsenek eszközök a megegyezések kikényszerítéséhez. Ennek eredménye a nyilvános közös gondolkodás összvolumenének csökkenése lehet, különösen a célok és az értékek tekintetében. 


\section{A fogyasztói szemlélet}

Az internet ethosza az áruválaszték. Az amerikai napilapok üzleti rovatai naponta tájékoztatják olvasóikat arról, hogy a számítógépes hálózatok hogyan segítik a fogyasztókat az árucikkek gyorsabb és kevesebb költséggel járó megtalálásában, mint ami azelôtt bármikor elképzelhetố volt. Az emberek hasonló könnyúséggel megtalálhatják azt a vallási közösséget, érdekcsoportot vagy politikai lobbit is, amely a legjobban megfelel a saját preferenciáiknak.

A bóséges áruválaszték értéket hordoz, és minden bizonnyal kívánatosabb, mint a zsarnokság. A fogyasztói szemlélet zabolátlan terjedésének különféle jelenségei azonban a civil társadalom szempontjából okot adnak az aggodalomra.

Először is, a fogyasztást gyakran kevésbé tiszteletre méltó és kevésbé értékes attitû́dnek tekintik, mint a termelést és a kreativitást. A katolikus egyház tanítása szerint „a munka jó dolog az ember embersége szempontjából, mivel a munkán keresztül az ember nemcsak átalakítja a természetet, saját szükségleteihez igazítva azt, hanem emellett kiteljesedik mint emberi lény is, és bizonyos értelemben valójában »még inkább emberi lénnyé « válik". Hannah Arendt hasonló szellemben szállt síkra az értékkel bíró tartós dolgok létrehozásához vezetố kreatív tevékenységként definiált <@0132>munka”, valamint az emberi lények megfontolt közös gondolkodáson alapuló együttmúködése, a „cselekvés” alapvetô fontossága mellett. Amikor bizonyos tevékenységeket „civil” cselekvésként vagy az állampolgárok méltó feladataiként írunk le, rendszerint a munka Arendt-féle meghatározása jár a fejünkben. Így például Harry Boyte a civil társadalom és a demokrácia fogalmait „le akarja söpörni az asztalról”. Azt állítja, hogy „a demokrácia nem elsôsorban intézmények együttesét jelenti, hanem inkább folyamatban levô munkát, melynek során az emberek folyamatosan megalkotják és újraalkotják a közérdekú dolgok sokaságát (beleértve a közintézményeket)”.

Az internet eredeti ígérete az volt, hogy mindenki kiadóvá, múvésszé vagy szoftverfejlesztő mérnökké válhat. Azoknak az internethasználóknak az aránya azonban, akik ténylegesen megalkotnak bizonyos anyagokat, drámaian lecsökkent. A Stanford Intézet kutatói úgy találták, hogy „az internet ma legnagyobbrészt olyan gigantikus közkönyvtárként múködik, amely határozottan a kommersz használat felé billen el. Az internetnek a legszélesebb körben elterjedt használati módja ma a haszonelvú információkeresés, tehát a világháló elsôsorban az erre szolgáló 'közmú' funkcióját tölti be, amelyet bizonyos termékek, utazások, hobbik és általános tájékozódás elérése érdekében vesznek igénybe. Gyakorlatilag minden megkérdezett felhasználó úgy válaszolt, hogy folytat egy vagy több ilyen jellegú információkeresési tevékenységet." $\mathrm{Ha}$ az internet megkönnyíti a fogyasztást, de javak - különösen ingyenes közjavak - létrehozására nem ösztönzi az embereket, akkor nettó mérlegét tekintve többet fog ártani a civil társadalomnak, mint amennyit használ.

Másodszor, az áruválaszték nem ugyanaz, mint a szabadság. Annak a kiválasztása, amit saját preferenciáink alapján látni akarunk vagy meg kívánunk vásárolni, nem bizonyítja önállóságunkat, mivel azt, hogy mit részesítünk elốnyben, esetleg anélkül döntöttük el, hogy tudatában lettünk volna az alternatíváknak és azokat is figyelembe vettük volna. Valaki, aki a vasárnapját a bevásárlóközpontban tölti és megvásárolja mindazt, amit akar, nem tekinthetô szabadnak, ha soha senki sem tekintette fontos ügynek, hogy 
az idejét például egy templomban, az erdóben, vagy egy politikai kampány elốre vitelével töltse. Az internet szúrési potenciálja csökkenti az esélyeket arra, hogy az emberek ki legyenek téve ilyen hatásoknak.

Egyes apostolok olyan közeljövót képzelnek el, amelyben kommunikációs berendezéseink - televíziós készülékeink, autórádióink és számítógépeink egyaránt-kivétel nélkül vezeték nélküli kapcsolattal csatlakozni fognak az internetre. A számítógépek minden egyes alkalommal, amikor úgy döntünk, hogy megnézünk, meghallgatunk vagy megvásárolunk valamit, fel fogják jegyezni ezt az információt, abból a célból, hogy meghatározzák, mit részesítünk elốnyben. Ennek alapján a továbbiakban a saját preferencia-profilunknak megfeleló, testre szabott reklámokat fogunk kapni. A hirdetók pénzt takarítanak meg, mivel „,nem akarnak pénzt kiadni arra, hogy reklámot juttassanak el olyan emberekhez, akik nem érdeklődnek termékeik iránt”. Lesznek megtakarítások a fogyasztók számára is, akik ily módon ,idôszerú és releváns információt fognak kapni”, és elkerülhetik ,a nem kívánt hirdetések és felhívások zsibvásárát”. Ha az effajta célzott kommunikáció jól múködik, akkor valóban megtörténhet, hogy a reklámozott dolgoknak nemcsak egy csekély töredékét fogjuk ténylegesen megkívánni, hanem majdnem mindent, aminek a reklámjával találkozunk. Fel fogjuk ismerni számos olyan kielégítetlen igényünket és törekvésünket is, amelyek egyébként nem tudatosultak volna bennünk. Ily módon tehát könnyen a kielégítetlen vágyak végtelen taposómalmában találhatjuk magunkat. Ez számomra a kiszolgáltatottság elrettentố képének túnik, mivel így saját múltbeli preferenciáink rabszolgájává válhatunk. Senki sem fog többé olyan célzott üzeneteket küldeni, amelyek arra szólítják fel a fogyasztókat, hogy legyenek aktívabbak saját közösségeikben, törődjenek többet a jövó generációkkal, többet jótékonykodjanak vagy legyenek tájékozottabbak a közéleti kérdésekben. Mint Andrew Shapiro megjegyezte: „Máris számtalan hírcsoport, levelezólista és más online információforrás létezik, amelyeket a lehetố legspeciálisabb érdeklódések kielégítésének szentelnek, de ugyancsak nehéz lenne az 'Általános Közjó' iránt elkötelezett csoportokat találni." A hatékonyabb kereskedelmi reklám eredményeként az a pénz és az az idő, amit a civil társadalmi tevékenységre fordítunk, jelentősen csökkenhet.

A harmadik problémát az jelenti, hogy az áruválaszték igen gyatra eszköz a kifejezés szabadságának megértéséhez. Szabadon akkor fejezhetjük ki magunkat, amikor cenzorálatlan üzenetekkel fordulhatunk valamely kiválasztott hallgatósághoz. Ennek a szabadságnak azonban mindig korlátozottnak kell lennie, mert egyébként egy-egy személy monopolizálhatná a köztereket, átvehetné az uralmat a privát fórumok fölött, vagy nem kívánt üzenetekkel állandóan zaklathatna más polgárokat. Gyakran feszültség alakul ki a között a jog között, hogy bárki elôtt szabadon kifejezzük magunkat, és az arra vonatkozó döntési jog között, hogy mit (és mit nem) akarunk látni és hallani. A tisztán fogyasztói döntések rendszerében azonban eltúnne a mások megszólításának szabadsága, mivel minden egyes személy teljesen szabadon választhatná meg, hogy milyen üzeneteket kíván fogadni (az üzeneteket itt fogyasztási terméknek tekintve). Ez az általános trend érvényesül az interneten. A valóságos világban az ember osztogathat szórólapokat egy utcasarkon vagy sztrájkốrséget állhat egy vállalat központja elôtt, az interneten azonban nincsenek eszközeink arra, hogy megszólítsuk azokat, akik böngészés közben elsiklanak egy adott honlap mellett (hacsak történetesen nem vagyunk annak a tulajdonosai). 
Az árukínálatból való választás - általánosabb szinten - nem az egyetlen mód a preferenciák kifejezésére. Kiválasztunk bizonyos árucikkeket a piacon, de megválasztjuk a foglalkozásunkat, a barátainkat, a társaságunkat és a politikai vezetôinket is. Ezeknek a másfajta választásoknak a logikája formálisan eltér a fogyasztói viselkedés logikájától. Amikor például támogatok valamilyen politikát vagy ideológiát azáltal, hogy rá szavazok, azt remélem, hogy döntésem valamilyen formában mindenkire ki fog hatni, ám amikor egy árucikket választok ki a bevásárlóközpontban, csupán a személyes hajlamaimat juttatom kifejezésre. Hasonlóképpen, amikor valamilyen fogyasztási terméket kiválasztok, nem tételezek fel semmiféle olyan kötelezettséget, mint amilyenek azzal járnak együtt, ha valamilyen személyes kapcsolatot kezdeményezek. A fogyasztók, a szavazók, a dolgozók és a társasági partnerek szerepei különbözóek, és ezek a szerepek eltérố készségeket, illetve attitûdöket kívánnak meg. A zabolátlan fogyasztási kultúrában elveszíthetjük azt a képességünket, hogy más szerepeinkben bölcsen hozzuk meg döntéseinket.

Az utolsó probléma a fogyasztói szemlélet inkompatibilitása az alternatív kulturális normákkal és értékekkel. Csak egyetlen példát említve erre: az Iszlám hívei a vallásukat nem tekintik olyan választási lehetőségnek, ami történetesen megfelel bizonyos emberek preferenciáinak, és ami változatos ízlések kielégítéséhez, sokféle színezettel rendelkezésre áll. Az Iszlám „alávetettséget” jelent: engedelmességet Isten hatalmának. Kétségtelen, hogy az emberek ma bárhol a világon - a www.islamonline.net és milliónyi más mozlim honlap révén - élhetnek a „fedezd fel az Iszlámot” lehetôségeivel. Letölthetik a Korán különféle forrásait, kutathatják a fatwák adatbázisait, és útmutatásokat kaphatnak mohamedán „kiber-tanácsadóktól”. Azok számára, akik már elkötelezett hívei az Iszlámnak, a számítógépes hálózatok hasznosnak bizonyulhatnak. Az internet azonban az Iszlámot is óhatatlanul úgy tünteti fel, mintha választás kérdése lenne, valami olyasmi, ami mellett az ember dönthet például a helyett a lehetôség helyett is (vagy ahhoz ráadásként), hogy környezeti kérdésekról olvasna, valamilyen sportcsapat karrierjét kísérné figyelemmel, vagy meztelen modelleket nézegetne. Az ,islamonline” honlap csupán néhány kattintásnyi távolságra van ezektól az alternatíváktól. A „behálózott" világban az Iszlámnak is közvetlenül versengenie kell az emberek figyelméért, és nem számíthat a hagyomány vagy a tekintély erejére, amivel a hívóket a megfelelő forrásokhoz irányíthatja és a megfelelő meggyőzódéseket alakíthatja ki bennük.

Egy felmérés, amit olyan amerikaiak körében végeztek, akik bizonyos kiválasztott keresztény honlapokat látogattak, azt mutatta, hogy az emberek legnagyobbrészt olyan gondolatokat, tanácsokat és történeteket kerestek, amelyeket saját ízlésük vagy elgondolásaik szerint a nekik megfelelő vallási csomaggá tudtak összeilleszteni. „Azoknak az embereknek az érdeklódését, akik a vallásról keresnek információt az interneten, nem szervezeti lojalitás vagy közösségi kapcsolatok motiválják. Ezek a felhasználók inkább olyan információt akarnak, ami segítségükre lehet nemcsak annak eldöntésében, hogy az intézményektól érkezó üzenetekre hogyan reagáljanak, hanem abban is, hogy hogyan hajtsanak végre egyéni akciókat." Más szóval, az amerikaiak úgy használják fel az internetet a vallási kérdések kezelésére is, mint ahogyan a fogyasztási javakat kezelik.

A privát fogyasztói döntések és a mély, kulturális vagy spirituális elkötelezettségek közötti konfliktust nem könnyú megoldani. Ha rászorítanának, a fogyasztói dönté- 
seket választanám, de sajnálkoznék is az óhatatlan veszteségek fölött. Az internet mindenféle egyéb hatásai mellett - csökkentheti a civil táradalom pluralizmusát, még akkor is, ha felhasználói gyakran éppen a változatosság forrásait keresik benne. Bizonyos kultúrák mégiscsak összeegyeztethetetlenek a korlátlan egyéni fogyasztás ideológiájával.

\section{A privát szféra sérelmei}

A civil társadalom megkíván bizonyos mértékú, sajátos típusú titoktartást. Az olyan közintézményeknél, mint például a bíróságok és a törvényhozó testületek, normális esetben minden tevékenységnek nyilvánosnak és átláthatónak kell lennie. Az olyan intim dolgokban, mint például az egészség, a szexualitás vagy a születésszabályozás, a magánélet jelenti a normát.'A civil társadalom különféle csoportjain belül azonban az állampolgárok szelektíven közzé tesznek bizonyos személyes információkat. A civil társaságok tagjai például nem feltétlenül hozzák a kívülállók tudomására a társadalmi kérdésekre vonatkozó nézeteiket, de egymás között véleményt cserélnek ezekról. A szomszédok megfigyelik egymást, ahogy vásárolnak vagy kertészkednek, de nem tudják, hogy a szomszédos ház lakói hogyan viselkednek a hálószobájukban vagy a szavazófülkében.

Az internet megváltoztatja a privát szféra természetét és határait. Lehetôvé teszi megjelenésünk, nemünk, korunk és faji hovatartozásunk tényeinek eltitkolását más emberek elól, akikkel kommunikálunk. A privát szféra ilyen potenciális kiterjesztésének megvannak a maga elónyei, de gyengítheti az intim horizontális kötelékeket, vagyis a polgárok olyan kapcsolatait, amelyekben egyenlő felekként vesznek részt. Ugyanakkor a számítógépes hálózatok tulajdonosai megszerezhetnek és áruba bocsáthatnak információkat mindazokról a személyekról, akik igénybe veszik szolgáltatásaikat. A számítógépek figyelemmel kísérhetik, hogy az emberek mit mondanak és kinek, milyen honlapokat látogatnak online, mit vásárolnak és mit adnak el. Sót mi több, képesek arra is, hogy - központilag nyilvántartott adatainkat hozzáadva a vásárlásaink listájából kialakított fogyasztói profilunkhoz - mindezeket az információkat aggregált formába öntsék. Az Aristotle International nevú vállalat például kiépített egy adatbázist 150 millió amerikai polgárról. A New York Times szerint

„az Aristotle adatbankja - egyéb források között a gépjármúvek állami nyilvántartása, a postaszolgálat és a népszámlálási hivatal adatai alapján - magában foglalja az egyes személyek korát, nemét, telefonszámát, párt-hovatartozását és becsült jövedelmét, otthonát illetően tulajdonosi vagy bérlői státusát, gyermekeinek számát, valamint azt is, hogy vezetékneve utal-e etnikai származására. Nyilvántartja ezen kívül a szavazók autóinak gyártmányát és típusát, s adatokat ốriz munkáltatójukra és foglalkozásukra vonatkozóan, továbbá arra nézve is, hogy mely kampányokat támogatnak és milyen gyakran szavaznak."

Ha az ilyen adatbázisokban tárolt információ esetleg téves, vagy félrevezetô megvilágításba kerül, akkor előfordulhat, hogy valaki ártatlanul rossz hírbe keveredik. Még a pontos és hiteles adatok is felhasználhatók erkölcsileg kifogásolható módokon az al- 
kalmazottak diszkriminálására. Az adatbázisok sérthetik továbbá a tulajdonjogokat is, hiszen egy személy „profilja” igazolhatóan az övé. A magánélet eróziója megakadályozhatja az embereket abban, hogy komplex személyiséggé fejlódjenek, mivel az érettség eléréséhez szükség van bizonyos eszmék és személyiségmodellek mások tudta nélkül történố kipróbálására. Az állampolgárok - annak eredményeként, hogy magánéletük sérelmeket szenved - egyszerúen boldogtalanabbá válhatnak.

Az ilyen adatbázisok nem csupán a személyes boldogságunkat és szabadságunkat károsíthatják, hanem alááshatják aะ önkéntes társulások fontosságát is életünkben, éppen azáltal, hogy kényszerítenek bennünket olyan dolgok nyilvánosságra hozatalára is, amelyeket jobban szeretnénk csupán valamely csoport tagjai számára fenntartani. Mivel pedig az emberekre vonatkozó információ a hatalom forrásai közé tartozik, azok a polgárok, akik elveszítik tényleges jogukat bizonyos információk visszatartására, a kormányokhoz és a nagy szervezetekhez képest gyengébbé válnak.

\section{Konklúzió}

Ennek a cikknek nem az volt a célja, hogy baljós elốrejelzéseket tegyen az internet valószínú hatásairól, amelyeket a civil társadalomra gyakorolhat. Az internet a civil társadalmi élet szempontjából végeredményben jótékonynak is bizonyulhat. A tanulmány mindössze azonosított néhány potenciális problémát, amelyeket még megoldhatunk. Az internetet nem szabad magára hagyni, hogy csupán ötletszerúen, véletlenül fejlődjön. Törvénnyel védhetốk olyan értékek, mint például a személyes adatok és a magánélet. Bizonyos kontextusokat, amelyekben az internet felhasználása folyik - különösen az iskolákat és a közkönyvtárakat - lehet olyan módon menedzselni, ami biztosítja, hogy a számítógépek a közjó céljait szolgálják. A gyerekeket meg lehet tanítani arra, hogy a hálózatokat kritikusan és a civil társadalom érdekeinek szem elő́tt tartásával használják. Különösen ígéretes reformjavaslat az az elgondolás, hogy a közszférában létre kell hozni olyan nyilvános online tereket, amelyek az állam támogatásával fenntarthatók a civil társadalom céljaira. Röviden: az internet nem hibáztatható azért, ha a civil társadalom helyrehozhatatlanul meggyengül - mi magunk érdemeljük meg a szemrehányásokat, ha elmulasztjuk, hogy idóben cselekedjünk.

Ez a munka egy korábbi tanulmány alapján készült, amely a The Report from the Institute for Philosophy and Public Policy címú sorozat 20. kötetében, 2000 őszén jelent meg. 


\section{Források és jegyzetek}

Pew Research Center for the People and the Press (1999): The Internet Audience Goes Ordinary. (www.peoplepress.org/tech98sum.htm)

US Department of Commerce, National Telecommunications \& Information Administration (NTIA) (1999): Falling Through the Net: Defining the Digital Divide. www.ntia.doc.gov/ntiahome/fttn99/contents.html)

Stanford Istitute for the Quantitative Study of Society (2000): Internet Study. (www.stanford.edu/group/siqss/Press_Release/internetStudy.html)

NTIA (2002. február): A Nation Online: How Americans are Expanding their Use of the Internet.

Leslie Harris and Associates (2002. július): Bring a Nation Online: The Importance of Federal Leadership.(www.benton.org)

Department of Education's National Adult Literacy Survey (NALS): http://www.nifl.gov/reders/reder.htm

Joseph Turow (1999): The Internet and the Family: The View from Parents, The View from the Press. Philadelphia: Annenberg.

Az Annenberg Public Policy Center felmérésébe bevont amerikai szülók 43 százaléka már 1999-ben egyetértett abban, hogy „azok a gyermekek, akiknek nincs internethozzáférésük, kortársaik között hátrányos helyzetben vannak..."

Amy Waldman (2001. február 19.): An American Block: Life on $129^{\text {th }}$ Street. New York Times.

U. N. Development Programme (1999): Human Development Report. Oxford: Oxford University Press.

D. C. Seyle (2000): Dot-Com Democracy: Computer-Mediated Communication, Community and Deliberation. (www.kettering.org)

A Kettering alapítvány felmérése szerint az internethasználók 49,3 százaléka mondta azt, hogy legtöbbször megbízik a legtöbb emberben, 91,7 százalékuk jelezte, hogy legalább egy csoportnak a tagjai közé tartozik; míg 71,3 százalékuk tartozott saját bevallása szerint legalább két csoporthoz. Ezzel szemben az internetet nem használó megkérdezetteknek csupán 33,1 százaléka mondta az, hogy legtöbbször megbízik a legtöbb emberben, ezeknek 80,3 százaléka mondta, hogy legalább egy csoportnak a tagja, és 54,6 százalékuk tartozott két vagy több csoporthoz is. Ezek a korrelációk általában validak maradtak a képzettségi szinttel és a jövedelemmel kontrollálva is, egyetlen kivétellel: noha mind a képzettségi szint, mind az internet-hozzáférés korrelál a bizalommal, azok, akik legalább 17 éven át folytattak formális tanulmányokat és nem volt internet-hozzáférésük, még nagyobb bizalommal fordultak másokhoz, mint azok a hasonló szinten iskolázott emberek, akik használták az internetet. Ezzel kapcsolatban lásd bővebben a $N E S$ adatait, amelyek elérhetók a www.csa.berkeley.edu:7502/archive.htm honlapon.

J. I. Cole (2000): The UCLA Internet Report: Surveying the Digital Future.

(www.ccp.ucla.edu/pages/internet-report.asp.)

Az UCLA felmérése szintén tartalmazott néhány negatív eredményt. Az internetfelhasználók azt mondták, hogy másoknál kevesebb idốt töltöttek a háztartásukban velük együtt élő személyek társaságában. A civil társadalom olyan értékeit, mint pél- 
dául az önkéntes feladatvállalás és a környezet védelme, magasabbra értékelték, mint mások (miközben ezeknél magasabb prioritást élvezett a „sok pénzt keresni” kifejezéssel jelzett cél). Továbbá ezek a válaszadók kevésbé bíztak az oktatásban. Meg kell jegyezni azonban, hogy ezeket az eredményeket nem vetették egybe a korra, oktatási szintre, nemre és jövedelemre vonatkozó jellemzókkel.

Pew Internet and American Life Project, Online Communities Survey (2001): www.pewinternet.org

Kraut, V. Lundmark - Patterson, M. - Kiesler, S. - Mukopadhyay, T. - Scherlis, W. (1998): Asocial technology that reduces social involvement and psychological well-being? American Psychologist, vol. 53.

A UCLA felmérése (lásd Cole 2000) alkalmából felkérték az embereket, hogy értékeljék az internet hatását saját társadalmi kapesolataik alakulására. A válaszadók általában úgy érezték, hogy a számítógépek fokozták kapcsolataikat családjukkal, barátaikkal és munkatársaikkal, míg a velük közös vallást követố, illetve a hozzájuk hasonló politikai meggyőződésû́ emberekkel való kapcsolataik csökkentek. Úgy vélték, hogy a szabadidốs érdeklő́désüket osztó partnerekkel való kapcsolataik szintén növekedtek, de csak igen kis mértékben. Úgy gondolom azonban, hogy az effajta retrospektív beszámolókat a legnagyobb kételkedéssel kell kezelni.

J. Van Tassel (1994): Yakety-Yak, Do Talk Back! PEN, The Nation's First Publicly Funded Electronic Network, Makes a Difference in Santa Monica, Wired, 2.01.

A. Joinson (1998): Causes and Implications of Disinhibited Behavior on the Internet. In Gackenbach, J. (ed.): Psychology and the Internet: Intrapersonal, Interpersonal, and Transpersonal Implications. San Diego: Academic Press.

J. Preece (1998): Empathetic Communities: Reaching Out Across the Web. ACM Interactions, vol. 5.

M. Friedman (1989): Feminism and Modern Friendship: Dislocating the Community. Ethics, vol. 99, 281.

B. Bimber (1998): The Internet and Political Transformation: Populism, Community, and Accelerated Pluralism. Polity, vol. 31.

C. Haythorthwaite - B. Wellman - L. Garton (1998): Work and Community Via Computer-Mediated Communications. In Gackenbach (ed.).

E. Reid: The Self and the Internet: Variations of the Illusion of One Self. In Gackenbach (ed.).

J. Arquilla - D. Ronfeldt (1999): The Advent of Netwar. In Athena's Camp: Preparing for Conflict in the Information Age. Edited by Arquilla and Ronfeldt. Santa Monica, CA: RAND.

A vezetốknek a választóik értékeivel és prioritásaival való megismerkedését szolgáló meghallgatások további tárgyalását illetóen lásd Peter Levine (2000): The New Progressive Era: Toward a Fair and Deliberative Democracy. Rowman \& Littlefield.

A. L. Shapiro (1999): The Control Revolution. New York: Century Foundation/Public Affairs.

M. Van Alstyne - E. Brynjolfssin (1997): Electronic Communities: Global Village or Cyberbalkans? (web.mit.edu/marshall/www/papers/CyberBalkans.pdf)

www.urbanlegends.com/politics/hitler_gun_control.html

D. Thompson (1999): E-mail from James Madison, re: Cyberdemocracy. In Democracy.com? Governance in a Networked World. Edited by E. C. Kamarck and J. S. Nye. Hollis, MD: Hollis Publishing.

A. O. Hirschman (1971): Exit, Voice, and Loyalty. Cambridge, MA: Harvard University Press. John Paul II. (1981): On Human Work. Laborem exercens, §29, §40. 
H. Arendt (1958): The Human Condition. Chicago: University of Chicago Press.

H. C. Boyte (1999): Off the Playground of Civil Society. The Good Society, vol. 9

K. O'Connor: The High Cost of Net Privacy. Wall Street Journal. (2000. március 7.)

K. Bedell (1998): The Extent and Nature of Religion on the Internet: A Report on a Ten Month Visit to the World of the Internet. United Methodist Communication and the Louisville Institute (www.religion-research.rog/report1.htm)

H. Nissenbaum (1998): Protecting Privacy in an Information Age: The Problem of Privacy in Public. Law and Philosophy, vol. 17.

L. Wayne: Voter Profiles Selling Briskly as Privacy Issues are Raised. New York Times (2000. szeptember 9.) 